\title{
ПРОФЕССИОНАЛЬНАЯ ПОДГОТОВКА СОТРУДНИКОВ ПОЛИЦИИ
}

Мальцева Т.В.

\section{ИСПОЛЬЗОВАНИЕ ИНТЕРАКТИВНЫХ МЕТОДОВ ОБУЧЕНИЯ В ОБУЧЕНИИ СОТРУДНИКОВ ПОЛИЦИИ}

$\mathrm{O}$ бучение психологии вообще, а юридической психологии, в частности, тесно связано с умением применять полученные теоретико-психологические знания на практике. В данной статье приведены педагогические технологии способствующие развитию умения применять теоретические знания на практике, а именно использование рабочих тетрадей, портфолио-процесса, кейс-метода в сочетании с социально-психологическим тренингом.

В настоящее время в современной высшей школе все более четко осознается мысль о том, что психология не отвлеченная наука, а важное звено в профессиональной подготовке любого специалиста.

Преподавание психологии имеет долгую историю. Уже несколько десятилетий практически во всех вузах изучается какаялибо психологическая дисциплина. Курсы различаются объемом, глубиной изучаемого материала, специфической направленностью содержания, но, так или иначе, являются составляющей психологии.

Методике преподавания психологии в высшей школе посвящено много работ ${ }^{1}$,

\footnotetext{
${ }^{1}$ Багдасарьян Н.Г., Иванченко Г.В. Психология в цикле социально-гуманитарных дисциплин в техническом вузе $\backslash \backslash$ Психологический журнал. 2000. Т. 21. №2. С. 108-112.; Бадмаев Б.Ц. Методикапреподаванияпсихологии.М.:-Владос, 1999.-304c.; Боярчук B.K. Методика преподавания психологии в вузе: Учебно-методическое пособие. - Ростов-н\Д., 1982. - 68 с.; Гинецинский В.И. Введение в методику преподавания психо-
}

в которых аккумулируется материал по технологиям разработки учебного курса, методам, средствам и приемам обучения психологии, методике чтения лекций, проведения семинарских и практических занятий, способов формирования мышления психологического склада и умения творчески применять психологические знания в профессиональной деятельности.

Юридическая психология как учебная дисциплина направлена на изучение психологических аспектов, связанных с применением правовых норм и участием в правовой деятельности. В современной высшей школе юридическая психология преподается не только будущим психологам, но и юристам, экономистам, управленцам. Особое внимание уделяется ей в образовательных заведениях правоохранительной системы.

Целью преподавания этого предмета выступает формирование психологической культуры будущего юриста, которая способствует повышению эффективности профессиональной деятельности, её гуманизации. В.И. Черненилов считает, что

логии: Курс лекций. Л.: - ЛГУ, 1983.; Карандашев В.Н. Методика преподавания психологии: Учебное пособие. - СПб.: Питер, 2007. - 250 с.; Левченко Е.В. Субъективнае ожидания студента и методика преподавания психологии \\Вопросы психологии. 1991. №2. С. 80-86.; Лызь Н.А. Методика преподавания психологии: учебное пособие $\backslash$ Ростов-н\., 2009. 414 с.; Ляудис В.Я. Методика преподавания психологии. - М.: МГУ, 1989. - 77 с. и другие. 
«... предназначение юридической психологии есть определенный способ понимания, изучения и служения человеческому бытию, мера благополучия которого должна стать единственным критерием эффрективности системы права и его применения. Человечество упаковано в праве, вопрос заключается только в мере гармонии. Именно в поиске ее видится нам великая экзистенциальная миссия юридической психологии »². Однако, как отмечали А.Р. Ратинов и Г.Х. Ефремова: «Юридическая психология лучше разработана не как наука, а как учебная дисциплина, ориентированная на популяризацию психологических знаний в учебном процессе»${ }^{3}$. Данная несогласованность проявляется в содержательном наполнении учебной дисциплины в вузах различных профилей.

Структура учебного курса «Юридическая психология» диффференцируется в зависимости от категории обучающихся и учебных планов вуза. Для многих студентов юридических фракультетов вузов предполагается не только изучение материала, непосредственно относящегося к предмету юридической психологии, но и овладение знаниями, умениями и навыками из различных отраслей психологической науки, в большей степени общей и социальной. Это обусловлено необходимостью фрормирования у будущих юристов, прежде всего базовых знаний в области психологии.

Одна из проблем преподавания юридической психологии заключается в том, что на многих юридических фракультетах студенты в рамках курса «Юридическая психология» впервые знакомятся с психологией как наукой. Таким образом, они впервые воспринимают теоретико-психологические знания в системе. Данный процесс для сту-

\footnotetext{
2 Черненилов В.И. Цивилизационная миссия юридической психологии // Прикладная юридическая психология. Прикладная юридическая психология - 2011, №1. С. 19-26.

${ }^{3}$ Ратинов А.Р., Ефремова Г.Х. К проблематике юридической психологии // Юридическая психология: сборник научных трудов - М., 1998. С. 3-11.
}

дентов является чрезвычайно сложным, поскольку для адекватного понимания и оперирования получаемой информацией им необходимо, во-первых, овладеть категориально-понятийным аппаратом психологической науки, а во-вторых, понять сущность психологических явлений, которые по своей природе феноменологичны, в-третьих увидеть высокую практическую значимость психологических знаний в профессиональной деятельности юриста. Это обуславливает необходимость оптимизации восприятия студентами информации, применения методов, способствующих формированию заинтересованного отношения студентов к изучаемому курсу.

В высших образовательных учреждениях МВД России изучается несколько психологических курсов. Курс «Психология» является базовой составной частью программы высшего профессионального образования и рассматривает вопросы, как общепсихологической теории, так и практическое применение психологии, специальные вопросы правоохранительной деятельности. Этот курс как бы является стартовой площадкой для изучения последующих курсов «Юридическая психология» («Психология в деятельности сотрудников органов внутренних дел») и «Этнопсихология», которые в большей степени носят конкретно-прикладной характер. Курс «Юридическая психология» («Психология в деятельности сотрудников органов внутренних дел») как правило, включает в себя изучение психологических аспектов судебного разбирательства, психологических закономерностей правовой социализации, психологических особенностей личности преступника и осужденного, преступное поведение, психологию преступных групп, психологические аспекты расследования преступлений, психологические аспекты исправления осужденного, психологические особенности юридической, правоприменительной и правоохранительной деятельности. 


\section{Профессиональная подготовка сотрудников полиции}

В поисках решения проблемы усиления практической направленности подготовки специалистов юридического профиля в вузах можно выделить несколько направлений, взаимосвязанных между собой и часто не существующих друг без друга 4 : использование новых информационных технологий, обеспечивающих практическую направленность в процессе изучения дисциплин, включенных в учебный план вуза; проведение практических занятий на базе профильных учреждений и практических органов; использование активных педагогических технологий (тренингов, сюжетноролевых игр, дискуссий и т.п.).

Обучение психологии вообще, а юридической психологии, в частности, тесно связано с умением применять полученные теоретико-психологические знания на практике. А.М. Столяренко отмечал, что юридическая психология как учебная дисциплина излишне теоретизирована и недостаточно практична 5 . Для преодоления подобной трудности необходимо научить студентов применять полученные в ходе теоретических занятий знания в профессиональной деятельности. Преобразование теоретико-психологических знаний в практическое русло весьма сложный и долгий процесс. Студенты-психологи обучаются этому на протяжении всей вузовской подготовки. Перед преподавателем психологии в юридическом вузе стоит не легкая задача обучения студентов-юристов практическим психологическим умениям за семестр. Это представляется весьма затруднительным, если учесть, что для эфрфективной работы в юридической сфере, в правоприменительной и правоохранительной системе необходимы умения и навыки

\footnotetext{
${ }^{4}$ Мальцеева Т.В. Реуцкая И.Е. Методы развития творческого потенциала студентов юридических факультетов на занятиях по юридической психологии (из опыта работы). Прикладная юридическая психология - 2011, №1. С. 79-83.

5 Столяренко А.М. Юридическая психология как учебная дисциплина // Энциклопедия юридической психологии - М., 2003. C.42.
}

творческого мышления, самостоятельной мыслительной деятельности, психологического изучения личности, визуальной психодиагностики, эфффективной коммуникации, установления психологического контакта, самооценки личности, разрешения конфрликтных ситуаций, психической саморегуляции, простейших научных исследований и т.д. Кроме того целесообразно обучить будущих юристов оценки степени и направленности влияния тех или иных источников информации на правовую психологию населения, выделять признаки правомерного и делинквентного поведения.

Для того чтобы решить столь трудную задачу необходимо особое внимание уделять организации семинарских и практических занятий, которые призваны реализовать такой принцип дидактики, как связь обучения с жизнью, теории с практикой.

Анализ результатов деятельности по обучению курсантов и студентов-юристов психологии свидетельствует, что использование практических заданий вызывает у данной категории лиц живой интерес к получению знаний и эмоционально-позитивное отношение к указанной дисциплине; активизирует развитие профессионально важных и профессионально значимых качеств личности, способствует совершенствованию правосознания, консолидирует учебную группу. В целом способствует формированию общекультурной и профессиональной компетентности студентов, что в результате положительно отразится на их последующей профессиональной деятельности ${ }^{6}$.

Решению выше обозначенных проблем способствует приведенные ниже педагогические технологии.

Обучение в рамках социально-психологических тренингов профессионального об-

\footnotetext{
${ }^{6}$ Мальиева Т.В. Реуцкая И.Е. Методы развития творческого потенциала студентов юридических факультетов на занятиях по юридической психологии (из опыта работы). Прикладная юридическая психология -2011 , №1. C. $79-83$.
} 
щения с использованием способствует не только реализации образовательной функции процесса обучения, активизации мыслительной деятельности; развитию интереса к предмету; развитию эмоциональности и открытости; вовлечению личности обучающегося в учебный процесс; формированию эстетической культуры, но и позволяет актуализировать единицу психологической науки - психологический факт, который сам по себе феноменологичен (т.е. мы изучаем не саму психологическую реальность, а ее субъективный образ), а существование, его в виде образа восприятия и понятия, как правило, противоречиво.

Предлагаемая педагогическая технология способствует реализации таких принципов высшего образования как: оптимального сочетания фундаментального и прикладного знания; доступности обучения на высоком уровне трудностей; сознательности и творческой активности; наглядности.

В своей работе мы рассматриваем возможность интеграции таких педагогических технологий как тренинг и кейс-метод. При организации тренинга по кейс-методу ${ }^{7}$ одна часть учебной группы будет следить за решением ситуации кейса своих однокурсников (опытной группы) через зеркало Гезелла ${ }^{8}$, что обеспечит возможность живого активного участия каждого обучаемого в решении заявленной проблемы, путем наблюдения друг за другом.

Данная методика предусматривает наличие возможности использования специ-

\footnotetext{
${ }^{7}$ Метод конкретных ситуаций (кейсов) - состоит в разборе практических ситуаций (case-study); основная цель - научить слушателей анализировать и структурировать информацию, выявлять ключевые проблемы, генерировать альтернативные пути решения, оценивать их, выбирать оптимальное решение и вырабатывать программы действий.

8 Зеркало Гезелла - полупрозрачное стекло, используемое в психологических лабораториях для осуществления наблюдения за поведением; оно сделано таким образом, что пропускает свет только в одну сторону, становясь прозрачным. Это позволяет видеть человека, но человек не замечает, что за ним наблюдают.
}

ализированного оборудования: двух смежных помещений соединенных зеркалом Гезелла. Аудитории так же должны быть оборудованы системой аудио - и видеотрансляции с возможностью сохранения, дублирования и оцифровки информации. В аудиториях предполагается установка мультимедийного проектора и экрана.

При проведении тренингов для каждого занятия предварительно соответственно теме разрабатываются кейсы с задачами-ситуациями. Предполагается деление группы на подгруппы, каждая из которых получает свой кейс. Задача подгрупп - решить ситуацию профессионального общения. Остальная часть группы работают в системе супервизорства с другой стороны зеркала Гезелла, выполняя задания преподавателя по анализу ситуации.

Разбор практических ситуаций или кейс-метод является одним из самых старых и испытанных методов активного обучения навыкам анализа проблем и подготовки решений.

«Работа с кейсом» приобретает в настоящее время всё большую популярность при обучении различным дисциплинам в вузах. Одним из преимуществ кейс-метода, на наш взгляд, является то, что это средство развития у студентов на основе знаний умений их практического применения, кроме того, его можно использовать на всех этапах обучения.

Учебные ситуации могут иметь разную профессиональную тематическую направленность от научно-популярных вопросов на начальном этапе обучения до проблем, связанных с узким профилем специальностей (следственная работа, дознание, оперативная работа и пр.) на последующих этапах. Другими словами проведение кейс-метода предполагает также и возрастание трудностей. Следует также помнить, что недостаточно однократного использование метода, его проведение должно быть многократно и регулярно. 
Цель кейс-метода - активизация студентов и повышение уровня учебной мотивации через стимулирование профессионального интереса.

Кейс-метод позволяет успешно выполнять следующие задачи: применять к практической ситуации полученные теоретические знания; активизирует усвоение знаний и накопление определенного багажа практической информации; способствует развитию коммуникативных навыков (среди них, таких как: умение поддерживать дискуссию, убеждать и слушать своих оппонентов, защищать собственную точку зрения, аргументировать противоположное мнение, контролировать себя и т.д.); развивает навык оценки поведения людей; развивать навыки анализа деловых ситуаций, диагностики и принятия решений, которые позволят им быть более успешными при решении похожих проблем в своей профессиональной деятельности; развивать творческие навыки.

Использование этого инновационного средства в обучении также требует переосмысления своих методологических позиций. Данный метод требует от преподавателя достаточной методологической культуры, больших интеллектуальных ресурсов, переосмысления большого количества информации.

Кейс-метод предполагает использование в процессе профессионального обучения особой формы учебного материала - кейса (от англ. case - случай). Кейс представляет собой описание профессиональной ситуации, представленной как правило в письменной форме. Данные ситуации с одной стороны должны соответствовать целям профессионального обучения, быть максимально приближенными к действительности, с другой стороны должно быть они должны быть подобраны таким образом, чтобы можно было пользоваться разными путями для решения.

Кейс может содержать указания на отношения и поведение участников со- бытий в виде высказываний, описания их действий и т.д. Материалом для кейса может послужить статья из газеты, видеозаписи, телефонный звонок и др. Описание ситуации может быть различно как по объему, так и степени детализации, может меняться степень насыщенности информацией.

Содержание кейсов периодически должно корректироваться в зависимости от изменений, которые происходят в профессиональной и социальной действительности.

Известно, что в психологии не бывает однозначно-правильных решений. Каждый студент, когда он решает кейсзадачи, должен выдвинуть свои варианты решения, при этом он учитывает и свои психологические и профессиональные знания.

Работа над кейсом не сводится к определению «правильного» и «неправильного» решения; различные подходы к решению выявленной проблемы могут быть рассмотрены на равных основаниях. В дискуссии по разбору различных вариантов решений следует проанализировать предлагаемые в них варианты, оценить их приемлемость и эффрективность в предложенных условиях. Процесс выработки решений составляет сущность метода разбора практических ситуаций, и этот процесс часто является не менее важным, чем само решение.

Рассмотрим конкретную схему проведения социально-психологического тренинга с использованием кейс-метода в специализированных аудиториях на примере одной темы.

Тема: «Социально-психологический тренинг профессионального общения» .

Цели занятия:

1. Ознакомление студентов с процедурой проведения занятия с использованием кейс-метода и специализированных аудиторий.

2. Формирование опыта группового принятия решений. 


\section{Полицейская деятельность 6 • 2013}

3. Развитие способности разрешать и предупреждать конфликтные ситуации.

4. Развитие умения вести переговорный процесс.

Оснащение: смежные помещения соединенные зеркалом Гезелла, оборудованные системой аудио - и видеотрансляции с возможностью сохранения, дублирования и оцифровки информации, два телефонных аппарата и ширма.

Кейс: В дежурную часть ОВД $\mathrm{N}$-ского района в 14.0023 марта 20... года обратилась гражданка Лукина Л.Л., владелица сети продуктовых магазинов района «Вкусная покупка», с заявлением о том, что 23 марта 20... года в 10.40 под дверь ее квартиры было подброшено письмо, текст которого напечатан с помощью принтера, следующего содержания:

«Ваш автомобиль «Тойота Ленд Крузер» находятся у нас. Государственный номер а 437 ау. В подлокотнике лежат фотографрии ваших детей, мальчика и девочки, шоколадка "Аленка», правое левое крыло машины поцарапано, на машине установлены газовые амортизаторы и усиленные пружины. Нам не нужна машина, нам нужны деньги, всего 500000 евро. Такая большая сумма не только за машину, но и за жизнь и здоровье ваших детей, которых мы тоже похитим, если вы не выполните наши требования. Сделаем мы это также легко, как и похитили машину. Деньги мы хотим получить наличными купюрами по 500 евро. 25 марта вы должны закопать деньги, помещенные в герметичный контейнер, на 83-ем километре М-ского шоссе с правой стороны по направлению на город М. Если пришедшего за деньгами человека арестуют или не будет денег, то ваша машина сгорит, а дети будут похищены. Когда мы полу- чим деньги и будем уверены в своей безопасности и в подлинности валюты, то позвоним вам домой и сообщим, где находится автомобиль».

Гражданка Лукина Л.Л. сообщила, что в 11.20 она пришла в личный гараж находящийся в гаражном кооперативе №3 и не обнаружила своего автомобиля. Дверь была открыта, замки не повреждены.

24 марта 20.. года в 12.30 на домашний телефон Лукиной Л.Л. был совершен звонок. В квартире в это время никто не находился. Похититель на автоответчик оставил следующую запись: «Место и время передачи денег изменяется, о чем будет сообщено дополнительно по телефону в 20.00.»

Задания к кейсу.

- При работе над ситуацией определите мотивы похищения, социальный статус похитителей, наличие специальных навыков, знаний или криминального опыт, принадлежность к криминальной среде (выбелите в отчете те основания, которые помогли вам сделать это заключение).

- Совершено ли преступление группой (на основании чего сделано заключение)? Дайте общую психологическую характеристику членов группы (пол, возраст, профессиональная принадлежность, образованность, особенности проявления эмоций, особенности мышления и т.д.)

- Распределите роли: сотрудники правоохранительных органов (1-2 человека); гражданка Лукина; злоумышленник (и).

- Определите цели возможных переговоров по телефону.

- Разработайте и проиллюстрируйте схему ведения переговоров по телефону. 


\begin{tabular}{|c|c|c|}
\hline Этап работы & $\begin{array}{c}\text { Действия } \\
\text { преподавателя }\end{array}$ & $\begin{array}{l}\text { Действия } \\
\text { студентов }\end{array}$ \\
\hline $\begin{array}{l}\text { Подготови- } \\
\text { тельный }\end{array}$ & $\begin{array}{|ll|}\text { 1. } & \text { Разработка кейса. } \\
\text { 2. } & \text { Разработка сценария тренинга. } \\
\text { 3. } & \text { Определение списка литерату- } \\
& \text { ры и заданий (могут отсутство- } \\
\text { вать) для подготовки студентов. } \\
\text { 4. } & \text { Определение микрогрупп. } \\
\end{array}$ & $\begin{array}{l}\text { 1. Ознакомление с предложенной ли- } \\
\text { тературой. } \\
\text { 2. } \\
\text { Самостоятельная подготовка. }\end{array}$ \\
\hline Основной & 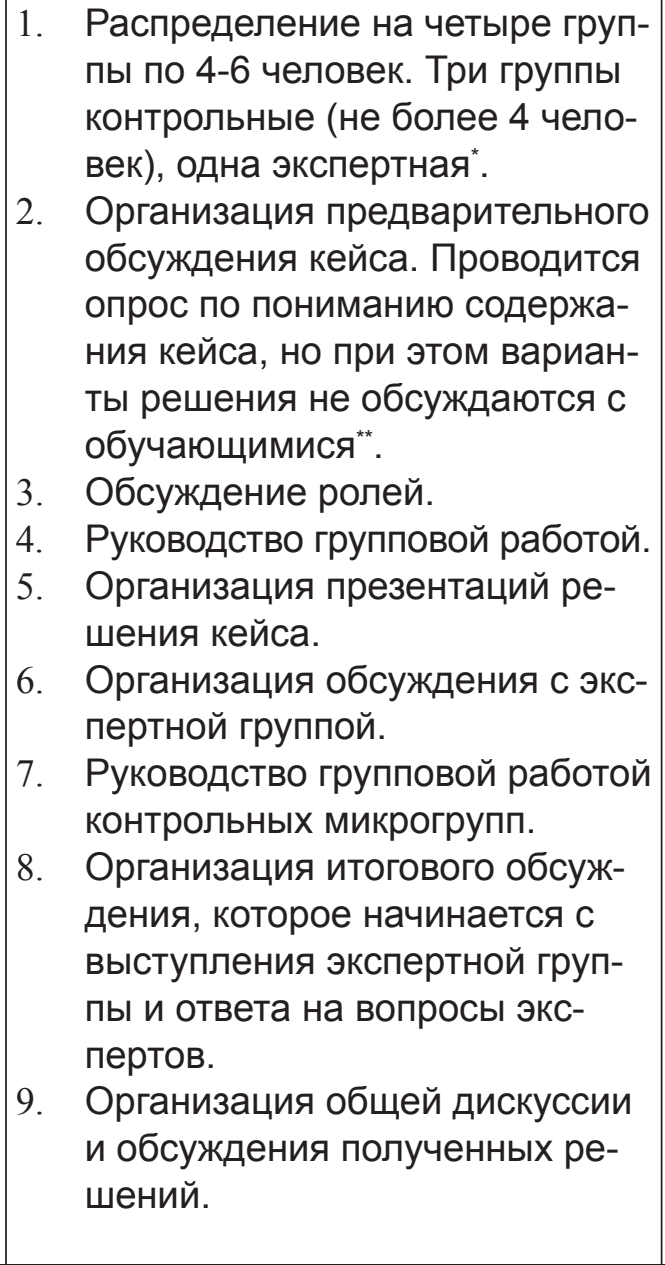 & $\begin{array}{ll}\text { 1. } & \text { Обучающийся знакомится с содер- } \\
\text { 2. } & \text { Станием кейса самостоятельно. } \\
& \text { преподавателя и задают встреч- } \\
& \text { ные вопросы, получают дополни- } \\
\text { тельную иноормацию. } \\
\text { 3. } \\
\text { 4. } \\
\text { Паспределение ролей в микрогруппах. } \\
\text { контрольной группой (продолжи- } \\
\text { тельность которой зависит от слож- } \\
\text { ности проблемы, примерно от 10 } \\
\text { до 20 минут). } \\
\text { 5. } \\
\text { Презентация решения кейса в } \\
\text { ролевом исполнении каждой кон- } \\
\text { трольной микрогруппой. } \\
\text { 6. Подготовка вопросов экспертной } \\
\text { группой для каждой из контроль- } \\
\text { ных групп, выработка своего экс- } \\
\text { пертного мнения. } \\
\text { 7. }\end{array}$ \\
\hline $\begin{array}{l}\text { Заключи- } \\
\text { тельный }\end{array}$ & $\begin{array}{l}\text { 1. Проводит обобщение полученных } \\
\text { результатов и приобретенных зна- } \\
\text { ний при работе над кейсом. }\end{array}$ & $\begin{array}{l}\text { 1. Подготовка письменных отчетов по } \\
\text { группам. }\end{array}$ \\
\hline
\end{tabular}

* Желательно комплектовать группы не по интересам, а по развитию способностей (чтобы не было в одной группе много активных обучающихся, а в другой - много пассивных).

** Обсуждение содержания кейса направлено на анализ и выявление всех заложенных ситуаций, проблем, но ни в коем случае преподаватель не помогает, не решает кейс.

*** Каждая контрольная группа должна познакомится с выступлениям других контрольных групп после своей презентации. Удобнее сначала провести выступление контрольной каждой группы так, чтобы они не наблюдали друг за другом. Преподаватель и экспертная группа наблюдают за презентациями через зеркало Гезелла. При подготовке экспертного мнения и вопросов экспертов проводится видеопросмотр зафиксированных презентаций контрольными группами, видеофиксация также оказывается нужна и экспертам при подготовке вопросов. 
Отчет студентов должен включать в себя этапы работы над кейсов, свой вариант видения ситуации кейса и свое решение, описание проблем, с которыми они столкнулись. Ответы на вопросы экспертов, обоснование своей позиции.

Целевая установка этой методики заключается в развитии у обучаемых умения, как при самостоятельной работе, так и при работе в группе анализировать информацию, структурировать ее, выявлять ключевые проблемы, генерировать альтернативные пути решения, оценивать их, выбирать оптимальные и вырабатывать программы действий, перекладывать полученные теоретические знания в практическое русло.

Нельзя поспорить с тем фрактом, что изучение любой науки в вузе подчинено цели научиться подходить к практическим профессиональным задачам с научных позиций, т.е. со знанием дела, изученного всесторонне. Применительно к психологии это означает, что каждый обучающийся должен научиться мыслить психологически, уметь ориентироваться в психологии человека, применять свои психологические знания в профессиональной деятельности. Изучение психологии как дисциплины в вузах должно способствовать полноценной подготовке будущих специалистов, поэтому ее преподавание в большей степени должно быть практико ориентировано.

Основой повышения качества системы подготовки высокопрофессиональных специалистов может выступать применение педагогических средств, интегрирующих новые и традиционные технологии. Сегодня в практике высшей школы становится популярной идея «портфолио» или портфеля, папки курса (В.К. Загвоздкин, Т.Г. Новикова, Б.И. Хасан, П.А. Сергаманов и др.). «Портфолио» считается важнейшим элементом практико ориентированного подхода к образованию. Педагогическая философия «портфолио» предполагает: смещение акцента с того, что учащийся не знает и не умеет, на то, что он знает и умеет по данной теме, разделу, предмету ${ }^{9}$. Данный метод переносит педагогический акцент с оценки преподавателя теоретических знаний по предмету на самооценку обучающимся своих умений и навыков применения этих знаний. Основой этой технологии является портфолио-процесс - выстраиваемая совокупность процессов обучения и учения, а также форм взаимодействия преподавателя и студента ${ }^{10}$. Движущая сила этого процесса - саморефлексия учащегося.

Технически «портфолио» представляет собой папку (скоросшиватель), в которую крепятся прозрачные фрайлы, или рабочую файловую папку. В папке содержится многообразная информация, которая иллюстрирует и документирует приобретенный теоретический и практический опыт обучающегося по курсу. Единицей сбора в «портфолио» являются: доклады, сообщения, самостоятельные исследования, подготовленные аудио- и видеоматериалы, творческие работы, компьютерные программы и т.д.

Формирование «портфолио курса» способствует реализации таких принципов высшего образования как оптимальное сочетание фундаментального и прикладного знания, сознательности и творческой активности, наглядности.

Как новая педагогическая технология «портфолио» несет на себе следующие функции:

- диагностическую, связанная с выявлением объективно существующего уровня владения умениями и навыками, а также пробелов в подготовке и трудностей усвоения;

\footnotetext{
9 Новикова Т.Г. Папка индивидуальных учебных достижений «портфолио»: федеральные рекомендации и местный опыт // Гуманитарное образование в школе: теория и практика, 2005, №5.

10 Загвоздкин В.К. Роль портфолио в учебном процессе. Некоторые психолого-педагогические аспекты // Психологическая наука и образование, № 4, 2004. С. 5-10.
} 
- мотивирующую, заключающуюся в формировании положительных мотивов учения и интереса к предмету;

- развивающую, связанную с развитием логики, умений анализировать, обобщать, систематизировать, классифицировать, мыслительной деятельности в целом и культуры мышления; критического отношения к собственной учебной деятельности; развитие.

B процессе организации самостоятельной деятельности обучающихся по формированию «портфолио курса» идет не только реализация образовательной функции процесса обучения, активизируется мыслительная деятельность студентов; развивается интерес к предмету, личность вовлекается в учебный процесс и фрормируется ее эстетическая культура. Это также способствует самостоятельному нахождению обучающимся областей актуализации полученных психологических знаний в профессиональной деятельности.

Кроме того, реализуются такие педагогические цели как повышение саморефлексивности и самоответственности по отношению к образованию; повышение уровня самостоятельности в организации процесса обучения (т.е. осуществили движение в сторону самообучения).

Собирая «портфолио», обучающимся необходимо рефлексивно трансформировать весь процесс обучения по курсу. Это связанно с пониманием и осознанием учебных целей, возможностями использования получаемых знаний в практической деятельности. «Портфолио» также является способом "аутентичного» (то есть истинного, наиболее приближенного к реальному) индивидуализированного оценивания.

Для преподавателей «портфолио» не только является современной педагогической технологией, эффрективной формой оценивания и организации самостоятельной работы обучающихся, но и помогает решать важные педагогические задачи:

- поддерживать высокую учебную мотивацию, активность и самостоятельность;

- расширять возможности обучения и самообучения;

- развивать навыки рефлексивной и оценочной (самооценочной) деятельности обучающихся;

- формировать творческие навыки обучающихся;

- формировать умения работать с книгой, первоисточником, библиотечным каталогом;

- формировать умение планировать и организовывать собственную учебную деятельность.

- В процессе организации деятельности обучающихся по фрормированию «портфолио курса», реализуются следующие цели:

- повышение саморефлексивности и самоответственности обучающихся по отношению к образованию;

- повышение самостоятельности в организации процесса обучения (т.е. движение в сторону самообучения);

- демонстрация возможностей практически применять приобретенные знания и умения;

- привлечение к процессу оценивания качества результатов обучения.

Во время работы по подготовке портфолио курса преподаватель должен не только рецензировать представленную работу, организовывать проведение её защиты и выставлять по результатам оценку, но и консультировать студентов по вопросам составления плана работы, использования библиологического материала и дополнительной литературы.

В качестве примера приведем план содержания «портфолио» по курсам «Юридическая психология», на который ориентируются студенты при начале изучения курсов. 


\section{План «портфолио» по курсу «юридическая психология»}

Резюме - представление себя.

I. Самостоятельные работы по теоретическим темам курса - этот раздел представляет собой собрание самостоятельных работ по темам курса. Материал по каждой теме должен быть систематизирован следующим образом:

1. Творческая работа по теме (текст доклада или сообщения, которые должны быть озвучены на семинаре, подготовленные аудио- или видеоматериалы, кроссворд, иллюстрации (литературные, художественные, исторические, документальные), самостоятельно подготовленные схемы или тесты, собранные иллюстрации, фотографии по определенной тематике, компьютерные программы и пр.)

2. «Это интересно» - этот подраздел может включать в себя проблемные вопросы, тезисы и высказывания, затрагивающие актуальные проблемы, изучаемой темы.

3. «Цитаты» - в этом подразделе собираются высказывания великих людей об изучаемой науке по конкретной теме, понравившиеся высказывания, изречения, с которыми пока трудно согласиться, но которые могут помочь обосновать собственную точку зрения.

4. «Голоса» - в этот подраздел помещаются вырезки или ксерокопии статей из журналов, газет и книг по проблемам конкретной темы изучаемой учебной дисциплины.

II. Самостоятельные работы по практическим темам курса. Материал по каждой теме должен быть систематизирован следующим образом:

1. Творческая работа по теме (выполненные на практическом занятии работы профессионально-личный жизненный план, собственный психологический портрет и т.д.; подготовленные аудиоили видеоматериалы; иллюстрации (литературные, художественные, исторические, документальные), самостоятельные исследования, самостоятельно подготовленные схемы или тесты, собранные иллюстрации и фотографии по определенной тематике с анализом, компьютерные программы и пр.).

2. «Полезные советы» - в этом подразделе собираются полезные советы, которые могут пригодиться в профессиональном будущем.

3. «Вредные советы» - в этот подраздел (не обязательный), носящий юмористический характер, вкладываются вредные советы (придуманные или собранные).

III. Библиография - в этом разделе собирается собственная библиография прочитанных изданий по изучаемой дисциплине с краткой аннотацией каждого издания.

IV. Справочник - в этом разделе собираются необходимые, полезные телефоны, адреса, ссылки и даты.

V. Самооценка «портфолио» самим студентом.

VI. Рекомендуемая литература для выполнения портфолио.

VII. Рекомендации по офрормлению портфолио.

Оформление практикума в виде «портфолио» в целом должно быть эстетически привлекательным и доступным для обзора со стороны. Первый лист является титульным и оформляется в соответствии с требованиями конкретного вуза.

Второй лист «портфолио» - резюме, структура которого курсантом разрабатывается самостоятельно (может содержать фотографию, краткую биографию, сведения об образовании, жизненные кредо и цели и т.д.).

Каждый раздел начинается с листа на котором его название, например, «Самостоятельные работы по теоретическим темам курса», «Библиография» и т.д. Следует также обозначать название тем и подразделов. 


\section{Профессиональная подготовка сотрудников полиции}

Каждая текстовая «единица сбора» в «портфолио» и листы с пояснением выполненной работы и аргументацией в защиту выбора вида данной работы выполняется на одной стороне листов формата A4 (210x297 мм) компьютерным текстом. Сокращать слова в тексте запрещается.

Применение в учебном процессе данной педагогической технологии не есть самоцель. Организация данного процесса должно иметь смысл в контексте профессионального образования. Поэтому исходным пунктом работы преподавателя с «портфолио» должна быть постановка перед собой задачи организации учебного процесса направленного на выработку умения и навыков практически применения обучающимися полученных психологических знаний в профессиональной сфере.

Одним из подходов к решению задачи повышения практической направленности подготовки специалистов является использование при обучении психологическим дисциплинам юристов рабочих тетрадей. С целью оптимизации обучения студентов юридических фракультетов в ходе практических и самостоятельных занятий была создана рабочая тетрадь. Данная тетрадь содержит упражнения эвристического и развивающего характера, активизирующие мыслительную деятельность студентов, их творческое и воссоздающее воображение, произвольное внимание и другие психические и эмоционально-волевые процессы. К этой тетради имеется мультимедийное приложение, в котором содержатся: «Словарь криминального жаргона», «Словарь асоциальных жестов», «Каталог уголовных татуировок», «Каталог преступников», образцы материалов уголовных дел. Указанные материалы представляют собой справочно-иллюстративное наполнение рабочей тетради, на основе материалов «Каталога преступников» и образцов уголовных дел проводится психологическое портретирование личности преступника.
Использование рабочей тетради в процессе обучения способствует:

- $\quad$ формированию умений и навыков практических действий, необходимых для грамотного выполнения функциональных обязанностей, предусмотренных профессиональной деятельностью;

- развитию навыков оценки и самооценки личности;

- фрормированию индивидуальной программы профессионального и личностного роста;

- обучению приемам визуальной психодиагностики;

- развитию коммуникативной компетентности и навыков разрешения конфликтных ситуаций;

- фрормированию навыков творческого мышления, самостоятельной мыслительной деятельности, логического рассуждения с опорой на научные аргументы и фракты;

- развитию умений делать собственные выводы, обобщать, анализировать и проводить простейшие научные исследования.

Каждая тема рабочей тетради представлена двумя блоками: повторение теоретических вопросов со ссылкой на рекомендуемую литературу, а также выполнение разнообразных практических заданий. Учебный материал ориентирован на повторение, углубление и систематизацию полученных ранее знаний, а также рассчитан на определенный контингент обучающихся, так как задания составлялись с учетом профессиональных потребностей обучающихся в юридическом вузе. При подготовке учебного материала учитывалась специфика вуза, акцентировалось внимание на использовании примеров из юридической деятельности.

Предлагаемые практические задания могут быть использованы как для обучения, так и для контроля. Кроме того, они содержат материал, позволяющий не только углублять знания обучаемых, но и развивать их творческие способности. 
Благодаря мультимедийному сопровождению преподаватель может по своему усмотрению распределять задания по вариантам, а также применять их с учетом разноуровневой подготовки обучающихся. Большинство заданий сформулировано таким образом, чтобы помимо усвоения базовых навыков, студенты могли повышать свою психологическую культуру.

В зависимости от содержания изучаемого материала и целевой установки в рабочей тетради предлагаются различные формы проведения занятий: деловые и ситуационно-ролевые игры, тренинги профессионального и личностного роста, а также социально-психологический тренинг.

Работа с тетрадями по психологическим курсам на занятиях должна занимать лишь определенную часть времени, которую главным образом целесообразно использовать для организации проверки, анализа и обсуждения в рамках занятия самостоятельной работы обучающихся.

Основное назначение рабочей тетради - создать необходимые условия для сознательного усвоения теоретических основ современной психологической науки; развития творческого потенциала; формирования устойчивого интереса к психологическим знаниям и применения их на практике; успешной самостоятельной работы; а также для помощи в актуализации полученных знаний в профессиональной copepe.

С целью овладения студентами навыками психологического изучения личности, усвоения приемов и методов психологического исследования, в рабочей тетради имеются задания на сравнительный анализ понятий, рефлексию теоретического материала (например, составление схем, графиков, таблиц), диффреренциацию понятий, а также психологические тесты и опросники, психологические задачи. В рабочей тетради также даются задания для самостоятельной работы обучающихся (проведение наблюдений и отдельных экспериментов, составление психологического портрета, после каждой темы предлагается провести самоанализ результатов).

Подводя итого, следует заметить, что методика преподавания дисциплины во многом зависит от поставленной цели и личности преподавателя. Если целью обучения юридической психологии является формирование психологического склада мышления, познание человека и развитие способов эффективного взаимодействия с другими, то и методика обучения должна способствовать успешному её достижению. Эффективность обучения дисциплине напрямую зависит от форм, методов и приемов избранных преподавателем. Coвременные требования к обучению в вузе предполагают использование интерактивных методов обучения, реализующих диалогово-дискуссионное сотрудничество преподавателя и студентов.

В заключение необходимо отметить, что выбор форм и методов обучения профессиональным знаниям, умениям и навыкам в любой современном вузе во многом зависит от целого ряда фракторов, таких как: особенности организации процесса обучения в конкретном вузе, особенности обучаемой профессии, характеристик профессорско-преподавательского состава, индивидуальных особенностей обучаемых (уровень образования, возраст и т.д.), а также от их численности.

\section{Библиография:}

1. Бадмаев Б.Ц. Методика преподавания психологии. М.: - Владос, 1999.

2. Боярчук В.К. Методика преподавания психологии в вузе: Учебно-методическое пособие. - Ростов-нД., 1982. 


\section{Профессиональная подготовка сотрудников полиции}

3. Гинецинский В.И. Введение в методику преподавания психологии: Курс лекций. Л.: ЛГУ, 1983.

4. Карандашев В.Н. Методика преподавания психологии: Учебное пособие. - СПб.: Питер, 2007.

5. Левченко Е.В. Субъективные ожидания студента и методика преподавания психологии // Вопросы психологии. 1991. №2.

6. Лызь Н.А. Методика преподавания психологии: учебное пособие Ростов-нД., 2009.

7. Ляудис В.Я. Методика преподавания психологии. - М.: МГУ, 1989.

8. Ратинов А.Р., Ефремова Г.Х. К проблематике юридической психологии // Юридическая психология: сборник научных трудов - М., 1998.

9. Столяренко А.М. Юридическая психология как учебная дисциплина // Энциклопедия юридической психологии - М., 2003.

10. Черненилов В.И. Цивилизационная миссия юридической психологии // Прикладная юридическая психология. Прикладная юридическая психология - 2011. №1.

11. Куракин А.В. Компетенция полиции в сфере реализации законодательства об административных правонарушениях // NB: Административное право и практика администрирования. - 2013. - 4. - С. 28 - 48. URL: http://www.e-notabene.ru/al/article_8841.html

12. Куракин А.В. Социальная политика и российская полиция // NB: Российское полицейское право. - 2013. - 3. - С. 1 - 23. URL: http://www.e-notabene.ru/pm/article_8914.html

\section{References (transliteration):}

1. Badmaev B.Ts. Metodika prepodavaniya psikhologii. M.: - Vlados, 1999.

2. Boyarchuk V.K. Metodika prepodavaniya psikhologii v vuze: Uchebno-metodicheskoe posobie. - Rostov-nD., 1982.

3. Ginetsinskii V.I. Vvedenie v metodiku prepodavaniya psikhologii: Kurs lektsii. L.: - LGU, 1983.

4. Karandashev V.N. Metodika prepodavaniya psikhologii: Uchebnoe posobie. - SPb.: Piter, 2007.

5. Levchenko E.V. Sub"ektivnye ozhidaniya studenta i metodika prepodavaniya psikhologii // Voprosy psikhologii. 1991. №2.

6. Lyz' N.A. Metodika prepodavaniya psikhologii: uchebnoe posobie Rostov-nD., 2009.

7. Lyaudis V.Ya. Metodika prepodavaniya psikhologii. - M.: MGU, 1989.

8. Ratinov A.R., Efremova G.Kh. K problematike yuridicheskoi psikhologii // Yuridicheskaya psikhologiya: sbornik nauchnykh trudov - M., 1998.

9. Stolyarenko A.M. Yuridicheskaya psikhologiya kak uchebnaya distsiplina // Entsiklopediya yuridicheskoi psikhologii - M., 2003.

10. Chernenilov V.I. Tsivilizatsionnaya missiya yuridicheskoi psikhologii // Prikladnaya yuridicheskaya psikhologiya. Prikladnaya yuridicheskaya psikhologiya - 2011. №1.

11. Kurakin A.V. Kompetentsiya politsii v sfere realizatsii zakonodatel'stva ob administrativnykh pravonarusheniyakh // NB: Administrativnoe pravo i praktika administrirovaniya. - 2013. 4. - C. 28 - 48. URL: http://www.e-notabene.ru/al/article_8841.html

12. Kurakin A.V. Sotsial'naya politika i rossiiskaya politsiya // NB: Rossiiskoe politseiskoe pravo. - 2013. - 3. - C. 1 - 23. URL: http://www.e-notabene.ru/pm/article_8914.html 